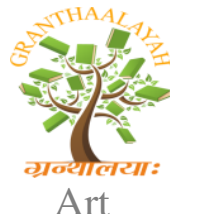

\title{
Synthetic Food Colors - Are They Safe?
}

\author{
Dr. (Mrs.) Jyoti Kulkarni, \\ Asst. Professor, Home Science, \\ Maharani Laxmibai Govt. PG Girls Collge, \\ Kila Maidan, Indore
}

\begin{abstract}
Colors in foods are always tempting whether they are natural or synthetic. Synthetic colors are commonly used in foods \& beverages as they are easily available, economic and intense whereas natural food colors are costly, availability is limited and range of color is also limited but whether synthetic colors are safe enough as far as health is concerned is a serious matter and to work over it is a matter of interest. To fulfil the ultimate goal of reducing the total exposure to colors, data on dietary intake of food colors needs to be generated urgently in the country.
\end{abstract}

\section{INTRODUCTION}

Color is the first notable characteristic of a food and often predetermines or "colors" our expectation. We use color as a way to identify a food and a way to judge the quality of a food.

Until the mid-1800s, the only external sources of colorings used in foods were natural: animals, vegetables, and minerals, including saffron, carrots, mulberries, flowers, and copper and iron ores. The first synthetic dye derived from organic coal tar entered the artistic palette in the latter part of the 19th century and first appeared in butter and cheeses. Demand increased for more varieties and more-stable and vivid colors, as more and more processed foods fed our growing nation. Refrigeration, canning, dehydration, smoking, bottling, and exposure to light, air, moisture, and temperature extremes all tend to alter the natural color, making color additives a hot commodity to restore expectations.

\section{CERTIFIED (SYNTHETIC) COLORS}

The first synthetic organic dye, a purplish lilac color, was discovered in 1856 by William Henry Perkin and called "mauve." Over the next 50 years, scores of similar organic aniline dyes, representing every color and tint of the rainbow, were developed, and many were used to color food with little thought or testing regarding their safety.

Of the 80 synthetic food colorants sold in 1907, only 16 were deemed to be "more or less" harmless. By 1907, this list was pared to seven synthetic colorants, which eventually were subjected to "batch certification" to detect and limit toxic impurities.

The list of "certified" colors has expanded and contracted over the decades to the current group of nine certified colors chemically classified into four chemical families: azo, xanthene/fluoroscein, triphenylmethane, and sulfonated indigoid (Table 1). 


\begin{tabular}{|c|c|c|c|}
\hline \multicolumn{4}{|c|}{ Table 1-Colors certified for use in foods. From CFR (2004d) } \\
\hline Certified color name & $\begin{array}{c}\text { Common or } \\
\text { industrial name (hue) }\end{array}$ & Uses and restrictions & CFR Regulations \\
\hline FD\&C Blue No. 1 & $\begin{array}{c}\text { Brilliant Blue } \\
\text { FCF(brilliant blue) }\end{array}$ & Foods generally & 74.101 \\
\hline FD\&C Blue No. 2 & $\begin{array}{c}\text { Indigotine(Royal } \\
\text { Blue) }\end{array}$ & Foods generally & 74.102 \\
\hline FD\&C Blue No. 3 & $\begin{array}{c}\text { Fast Green FCF (sea } \\
\text { green) }\end{array}$ & Foods generally & 74.203 \\
\hline Orange B & - & $\begin{array}{c}\text { Casings or surfaces } \\
\text { of frankfurters and } \\
\text { sausages }\end{array}$ & 74.250 \\
\hline FD\&C Red No. 3 & $\begin{array}{c}\text { Erythrosine (cherry } \\
\text { red) }\end{array}$ & Foods generally & 74.302 \\
\hline FD\&C Red No. 40 & $\begin{array}{c}\text { Allura Red AC } \\
\text { (orange-red) }\end{array}$ & Foods generally & 74.340 \\
\hline FD\&C Yellow No.5 & $\begin{array}{c}\text { Tartrazine (lemon } \\
\text { yellow) }\end{array}$ & Foods generally & 74.705 \\
\hline FD\&C Yellow No. 6 & $\begin{array}{c}\text { Sunset yellow } \\
\text { (orange) }\end{array}$ & Foods generally & 74.706 \\
\hline
\end{tabular}

Synthetic certified colors remain the most popular type of food colorings, as they are brighter, more uniform, better characterized, and of higher tinctorial strength, encompass a wider range of hues, and are less expensive than colors derived from nature.

\section{EXEMPT (NATURAL) COLORS}

Natural colors have always been part of the diet. They have been isolated and added back to foods for the same reasons as the certified colors - identity and appeal. Chlorophylls, carotenoids, and anthocyanins are consumed in the foods we eat every day. Common natural colorings include annatto, saffron, paprika, grape skins, zinc oxide, caramel, beetroot, cochineal, and turmeric (Table 2). FDA uses the term "exempt color additives" to indicate that they are exempt from the certification process. From the United States regulatory perspective, for the remainder of this article "exempt" will be used instead of "natural" when referring to these types of colors.

Presently, eight synthetic food colors, viz. Erythrosine, earmoisine, ponceau 4R indigo carmine, brilliant blue FCF, fast green FCF, tartrazine \& sunset yellow FCF, are permitted to be added to specified level of food color that can be added to any food was $200 \mathrm{ppm}$.. It is mandatory to declare the addition of artificial color on the label of food item for sale. These specifications have been laid down by Prevention of Food Adulteration (PFA). 


\section{TOXICITY OF COLORS USED IN FOODS}

The use of certain dyes has been banned as they are well known for their toxicity in experimental animals. Auramine was found to inhibit growth \& lead to dysfunction of the liver \& kidney. Metanil yellow consumption could lead to degenerative changes in stomach, ileum, rectum, kidney, liver, ovary \& testis. Rhodamine B was shown to cause retardation of growth, haemolysis of red blood cells and dangenerative changes in liver \& kidney. It also adversely affected the immune system. Sudan dyes were found to be toxic to the liver \& produce kidney lesions. Orange II led to retardation of growth, increased mortality and haematological changes. Malachite green caused a decrease in food intake, growth rate \& fertility rate,. It also caused damage to organs like liver, kidney, heart and spleen as well as lesions of skin, eyes, lungs \& bones. All the above colors are also mutagenic and most of them have been identified as potential carcinogens.

In humans, some of these dyes have been shown to lead to acute food poisoning outbrakes. Metanil yellow, the most commonly used non-edible, chemical dye, has been reported to cause symptoms of giddiness, weakness, vomiting and cyanosis. The people who developed these symptoms in two separate incidents had eaten foods like ladoo \& biryani colored with metanil yellow. Lead chromate added as a colourant to chilli powder caused lead poisoning among Gurkha soldiers with symptoms of epigastric pain, nausea, constipation \& anaemia.

\section{PERMITTED COLORS}

The permitted colors are also not totally safe. High levels of erythrosine intake known to cause thyroid tumors, Ponceau 4R, tartrazine and sunset yellow have provoked allergic reactions in several individuals even at low levels of intake. The allergic responses vary from urticaria to dermatitis, angioedema and exacerbation of the condition of patients with asthma. The incidence of tartrazine sensitivity appears to be higher in asthmatics. Persons who are sensitive to aspirin may also be sensitive to tartrazine and hence should avoid foods and even medicines having this yellow dye. Allergic reactions have also been seen in some people who consumed foods to which natural colors like annatto and carmine has been added.. A study was conducted by National Institute of Nutrition in which school children consuming a particular brand of aniseed (saunf) exhibited symptoms of glossitis of tongue. Analysis revealed that the aniseed (saunf) had very high levels Ponceau 4R.

\begin{tabular}{|c|c|c|c|c|}
\hline \multicolumn{5}{|c|}{ Dangerous Food Additives table } \\
\hline Additive Number & Name of Food Additive & $\begin{array}{l}\text { Hyper } \\
\text { activity }\end{array}$ & Asthma & Cancer \\
\hline $102 \&$ E102 & Tartrazine (food color) & $\mathrm{H}$ & A & $\mathrm{C}$ \\
\hline
\end{tabular}




\section{INTERNATIONAL JOURNAL of RESEARCH -GRANTHAALAYAH}

ग्रन्यलिया: A knowledge Repository Art

\begin{tabular}{|c|c|c|c|c|}
\hline $104 \&$ E104 & Quinoline Yellow (food color) & $\mathrm{H}$ & A & $\mathrm{C}$ \\
\hline $107 \&$ E107 & Yellow 2G (food color) & $\mathrm{H}$ & A & $\mathrm{C}$ \\
\hline $110 \& \mathrm{E} 110$ & Sunset Yellow (Yellow food color \#6) & $\mathrm{H}$ & A & $\mathrm{C}$ \\
\hline $120 \&$ E120 & Carmines, Cochineal (food color) & $\mathrm{H}$ & A & - \\
\hline $122 \& \mathrm{E} 122$ & Azorubine, Carmoisine (food color) & $\mathrm{H}$ & A & $\mathrm{C}$ \\
\hline $123 \& \mathrm{E} 123$ & Amaranth (Red food color \#2) & $\mathrm{H}$ & A & $\mathrm{C}$ \\
\hline $124 \&$ E124 & Ponceau, Brilliant Scarlet (food color) & $\mathrm{H}$ & A & $\mathrm{C}$ \\
\hline $127 \&$ E127 & Erythrosine (Red food color \#2) & $\mathrm{H}$ & A & $\mathrm{C}$ \\
\hline E128 & Red 2G (Red food color) & $\mathrm{H}$ & A & $\mathrm{C}$ \\
\hline $129 \&$ E129 & Allura Red AC (food color) & $\mathrm{H}$ & A & $\mathrm{C}$ \\
\hline E131 & Patent Blue (food color) & $\mathrm{H}$ & A & $\mathrm{C}$ \\
\hline $132 \& \mathrm{E} 132$ & Indigotine, Indigo Carmine (food color) & $\mathrm{H}$ & A & $\mathrm{C}$ \\
\hline $133 \&$ E133 & Brilliant Blue (food color) & $\mathrm{H}$ & A & $\mathrm{C}$ \\
\hline $142 \& \mathrm{E} 142$ & $\begin{array}{l}\text { Acid Brilliant Green, Green S, Food Green (food } \\
\text { color) }\end{array}$ & $\mathrm{H}$ & A & - \\
\hline 143 & Fast Green (food color) & - & A & - \\
\hline $150 \& \mathrm{E} 150$ & Caramel (food color) & $\mathrm{H}$ & - & - \\
\hline $151 \& \mathrm{E} 151$ & $\begin{array}{l}\text { Activated Vegetable Carbons, Brilliant Black (food } \\
\text { color) }\end{array}$ & $\mathrm{H}$ & A & $\mathrm{C}$ \\
\hline 154 & $\begin{array}{c}\text { Food Brown, Kipper Brown, Brown FK (food } \\
\text { color) }\end{array}$ & $\mathrm{H}$ & A & $\mathrm{C}$ \\
\hline $155 \& \mathrm{E} 155$ & Chocolate Brown HT, Brown HT (food color) & $\mathrm{H}$ & A & $\mathrm{C}$ \\
\hline $160 \mathrm{~b} \& \mathrm{E} 160 \mathrm{~b}$ & $\begin{array}{l}\text { Bixin, Norbixin, Annatto Extracts (yellow, red to } \\
\text { brown natural colors) }\end{array}$ & $\mathrm{H}$ & A & - \\
\hline
\end{tabular}




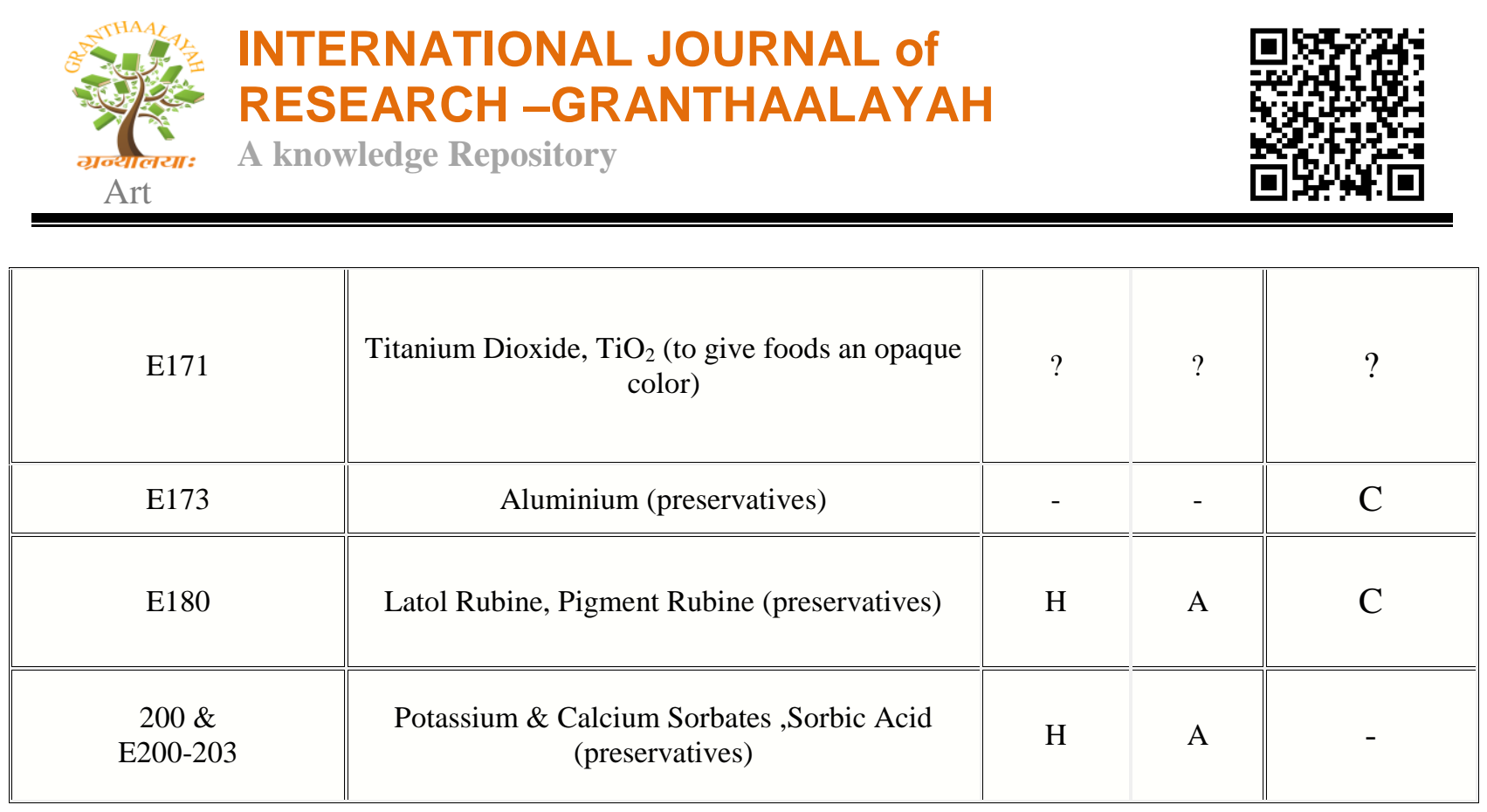

\section{CONCLUSION}

There is valid scientific evidence to show that even permitted food colors can prove to be toxic if used/consumed indiscriminately. For the sake of consumer safety it is important that the use of synthetic colors in foods be slowly phased out. Consumers have an important role to play in the ensuring their safety. The basic reason which manufacturers give for adding colors to food products is to improve the appearance and consumer appeal. Thus if the consumer demands food which is not artificially coloured, it will go a long way in solving the problem at hand. Manufacturers of processed foods and other users need to look for safer alternatives to synthetic food dyes.

\section{REFERENCES}

1. James C. Griffiths- Coloring Foods \& Beverages, Food technology May 2005, Vol. 59 No. 5 pp 38-40

2. Bhat Ramesh V \& Mathur Kulki - Changing Scenario of Food colors in India, Current Science, Vol. 74, No. 3 Feb 1998 pp198-202

3. Judith E. Brown - Nutrition Now, University of Minnesota

4. Google 